\title{
33 頭頸部悪性リンパ腫の臨床経過
}

\author{
湊川徹 - 是成信利 - 雲井健雄 \\ （兵庫医大 耳）
}

菱川良夫・三浦貴士

（兵庫医大 放）

昭和 49 年 5 月から 53 年 6 月まで兵庫医大耳鼻 科と放射線科が協力して診療にたずさわった頭頸 部悪性リンハ腥患者の内訳は男 23 例, 女 12 例 の計 34 例である。 40 才以上が全体の $70 \%$ を占める。 腫瘍の臟器別原発巣の内訳结口蓋扁桃と顓部腫瘦 が最も多く $68 \%$ を占める。副鼻腔例は 1 例のみで ある。初訅時頸部リンパ腺腫脹を主訴とし耳鼻科 的検査の結果, Waldayer Ring, 口腔, 鼻腔等に 䤚痛を認めなかったものを一応頸部腫㢞とみなし た。St二的の分類し関してはいずれの症例につい ても全身リンパ節触知の有無の検索, リンバ管造 影を施行し頸部腫瘳以外のものはU I CC の Head \& Neckの TNM 分類法に, 頸部腫瘁に関しては ホシキン氏病の Stage 分類法に従った。又各症例 に生検を行い Rappa port の分類法に従い組織診断 を行った。全体の各年每に於ける粗生存率を検討 した。Stage I, II 群と III, N 群について比較す ると両者の間には $1 \sim 3$ 年の間でかなりの差が認 められる。原発巣にかかわりなく初診時頸部りン 八腺の触知の有無により生存率を比較すると, 触 知例 19 例, 非触知例 15 例であり, 夫々の群の粗 生存率は 3 年生存率に於いて差がみられる。触知 群 $77 \%$ 非触知群 $42 \%$ である。 3 年間追跡の 20 例 を頸部リン八゙節触知の有無に分けて組織学的に分 類してみた。組織の分化程度とリン八゙節転移との 関係については症例数が少く, 決論的なことはい えない。両群の間に差が認められるのは Mixed cell lymphomaの Type である。非ホジキン例 で
本 type の占める割合は頸部リンパ節触知群 $0 \%$ ， 非触知群では 6 例中 3 例の $50 \%$ である。本 type が比較的リンパ節転移の少いことを物語っている。 Kiel の分類に従らと本 type は centrolytic 又は centroblastic lymphomaのいずれかに属し組織 学的に比較的 low grade malignancy $の$ type に 属する。この 3 例中 2 例が扁桃, 1 例が舌根部の 症例であり 3 例とも 3 年生存をしている。組織学 的な分類が臨床的な予後を推定するのに極的重 要であることを物語っている。全症例中 mxied cell lymphoma は5 例にみられ, うち 4 例は口 蓋及び舌根扁桃にみら机他の 1 例は上咽頭のもの である。次に 3 年以内に死亡者の内訳をみると口 蓋扁桃例では夫々 3 例と 1 例, 上咽頭夫々 4 例と 1 例であり頸部リンパ節転移を起こすものが非転 移群の $3 \sim 4$ 倍の高率で死亡している。以上より 悪性リンハ腫の取扱については組織学的性状と頸 部リンパ節転移の有無により治療方針を慎重に決 めなければならないと考光る。 